\title{
A sequence-specific DNA-binding protein that activates fushi tarazu segmentation gene expression
}

\author{
Hitoshi Ueda, ${ }^{1,2}$ Sandra Sonoda, ${ }^{3}$ J. Lesley Brown, ${ }^{1}$ Matthew P. Scott, ${ }^{3}$ and Carl Wu ${ }^{1,4}$ \\ ${ }^{1}$ Laboratory of Biochemistry, National Cancer Institute, National Institutes of Health, Bethesda, Maryland 20892 USA; \\ ${ }^{2}$ National Institute of Genetics, Mishima, Shizuoka-ken 411, Japan; ${ }^{3}$ Department of Molecular, Cellular, and Developmental \\ Biology, University of Colorado, Boulder, Colorado 80309 USA
}

\begin{abstract}
The Drosophila segmentation gene fushi tarazu $(f t z)$ is expressed at the cellular blastoderm stage in a pattern of seven transverse stripes; the stripes lie out of register with the segmental primordia, spanning alternate segmental boundaries. The zebra element, a 740-bp DNA sequence upstream of the $f t z$ translational start, directs striped expression of $I a c Z$ when introduced into the fly genome. We have purified to homogeneity a sequence-specific DNA-binding factor, FTZ-F1, that binds to two sites located within the zebra element and to two sites within the $f t z$ protein-coding sequence. FTZ-F1 DNA-binding activity is first detected in extracts of 1.5- to 4-hr embryos, coincident with the time of $f t z$ expression in stripes; the activity then diminishes before reappearing during late embryo, larval, and adult stages. When one of the FTZ-F1-binding sequences in the zebra element is mutated by 2 - or 4-base substitutions, the binding to FTZ-F1 is disrupted in vitro, and the intensity of lac $Z$ expression is reduced in transformed embryos, especially in stripes $1,2,3$, and 6 . The results suggest that FTZ-F1 is a transcriptional activator necessary for the proper expression of the ftz gene.
\end{abstract}

[Key Words: FTZ-F1; fushi tarazu; ftz gene]

Received August 2, 1989; revised version accepted January 16, 1990.

The subdivision of the Drosophila embryo into individual metameres, or segments, is governed by a hierarchy of maternal and zygotic genes (for reviews, see Akam 1987; Nüsslein-Volhard et al. 1987; Scott and Carroll 1987; Ingham 1988). The fushi tarazu (ftz) gene is a member of the pair-rule class of segmentation genes that are expressed with double segment periodicity in the early embryo (Nüsslein-Volhard and Wieschaus 1980). Embryos homozygous for $\mathrm{ftz}$ mutations possess half the normal number of body segments and die late in embryogenesis (Wakimoto and Kaufman 1981). Cloning and sequence analysis of the $f t z$ gene have revealed a 1239 -bp open reading frame that is interrupted by a 150bp intron (Kuroiwa et al. 1984; Laughon and Scott 1984; Weiner et al. 1984). The 413-amino-acid ftz polypeptide contains a homeo domain, suggesting that the protein can bind to DNA (for review, see Gehring and Hiromi 1986; Gehring 1987; Scott et al. 1990). Furthermore, the $\mathrm{ftz}$ gene is able to activate transcription of a reporter gene when introduced into cultured Drosophila cells (Jaynes and O'Farrell 1988; Han et al. 1989; Winslow et al. 1989) or in the yeast Saccharomyces cerevisiae (Fitzpatrick and Ingles 1989|. The results suggest that the $f t z$ protein functions as a transcription factor in these assays.

RNA gel blot analysis indicates that the $1.9-\mathrm{kb} f t z$ transcript is expressed maximally in 2- to 4 -hr embryos

${ }^{4}$ Corresponding author. and again at a lower level in 8- to 12 -hr embryos (Kuroiwa et al. 1984; Weiner et al. 1984). In situ hybridization studies of sectioned embryos localize ftz RNA to seven evenly spaced bands that encircle the embryo at 2-3 hr after fertilization. (Hafen et al. 1984; Weir and Kornberg 1985). The seven bands, or stripes, are located in the even parasegmental primordia (Lawrence et al. 1987) and are approximately coincident with the primordia of the body elements that are missing in $\mathrm{ftz}^{-}$ embryos. $f t z$ protein can be detected within the nuclei of these seven stripes by the immunostaining of whole embryos (Carroll and Scott 1985; Krause et al. 1988). In addition, $f t z$ protein is also detected at 5-12 hr of embryogenesis, in a segmentally repeated subset of neuronal precursor cells of the ventral nervous system (Carroll and Scott 1985; Doe et al. 1988) and at 12-15 hr of embryogenesis, in a section of the hindgut (Krause et al. 1988).

Previous analyses of the expression of $f t z-l a c Z$ hybrid genes in transformed embryos revealed that a striped pattern of lac $Z$ activity (at the germ-band-extended stage) is conferred by cis-acting DNA sequences included within $740 \mathrm{bp}$ upstream of the translational start; this control region has been referred to as the zebra element (Hiromi et al. 1985). A region $2.45 \mathrm{~kb}$ upstream of the translational start is required for $1 a c Z$ expression in the nervous system, whereas a $2.7-\mathrm{kb}$ region from -6.1 to $-3.4 \mathrm{~kb}$ upstream acts as an enhancer of $l a c Z$ expression in stripes in the embryonic ectoderm. Without the 
enhancer element, lac $Z$ expression is observed almost exclusively in mesodermal cells. The enhancement in ectodermal cells is dependent on the presence of $f t z$ protein, thereby introducing a positive feedback loop into the regulation of $\mathrm{ftz}$ gene expression (Hiromi and Gehring 1987). Cis-acting sequences necessary for $f t z$ expression in the gut have not yet been located.

As defined by the $f t z-l a c Z$ fusion experiments, the zebra element includes 670 nucleotides of $f t z$ upstream sequence, as well as 70 nucleotides of apparently untranslated $f t z$ leader sequence. Although the leader sequence could contribute to the spatial restriction of $f t z$ mRNA by differential mRNA stabilization, the $f t z$ message does not appear to be differentially stabilized within the Drosophila embryo (Edgar et al. 1986). Furthermore, constructs that eliminate all of the $f t z$ leader sequences still retain the ability to form seven stripes in the mesoderm of germ-band-extended embryos (Dearolf et al. 1989). Hence, the spatial restriction of $f t z$ expression is controlled primarily at the level of transcription.

The periodic expression of the $f t z$ gene is altered in a subset of the Drosophila mutants known to cause specific segmentation defects: All four gap segmentation mutants (Krüppel, hunchback, knirps, and giant), a terminal gene (tailless; Mahoney and Lengyel 1987), and three of seven pair-rule segmentation mutants [hairy $(h)$, runt (run), and even-skipped (eve)] affect the striped pattern of $f t z$ (Carroll and Scott 1986; Howard and Ingham 1986; Frasch and Levine 1987; Hiromi and Gehring 1987). At present, it is unclear whether these loci regulate the activity of the $\mathrm{ftz}$ gene as direct transcriptional activators or repressors, or by regulating indirectly the syntheses or activities of known or as yet unidentified transcription factors.

We have initiated a biochemical study, intended to complement the genetic studies, to define trans-acting components that regulate periodic $f t z$ transcription. Our approach is to identify proteins that directly interact with cis-acting elements, excluding those components that are one or more steps removed in the regulatory hierarchy. We have screened for sequence-specific DNAbinding proteins that interact with the $f t z$ zebra element in vitro. A combination of gel mobility-shift and exonuclease III (ExoIII) protection assays has revealed multiple factors that bind to distinct sequences within the zebra element (J.L. Brown, H. Ueda, and C. Wu, unpubl.). Here, we report the purification of one of these factors, FTZ-F1 (factor 1), whose DNA-binding activity appears in two phases during development. We show that mutations of the DNA sequence to which this factor binds result in a loss of the binding interaction in vitro and a change in the pattern of zebra element-dependent transcription in vivo.

\section{Results}

FTZ-F1 activity in developmentally staged extracts

ExoIII protection experiments performed in vitro reveal an activity in late (16- to 22-hr) embryo extracts that binds specifically to a $21-\mathrm{bp}$ sequence located at positions -293 to -273 upstream of the $f t z$ transcription start site. (The transcription start site was mapped by primer extension analysis (P. Becker and C. Wu, data not shown) and is in agreement with Dearolf et al. (1989). A previous mapping (Laughon and Scott 1984) indicated a site 50 nucleotides upstream, in keeping with a cDNA sequence; the discrepancy may have been due to a strain difference.] The sequence-specific DNA binding activity, designated FTZ-F1, was analyzed by the gel mobility-shift technique using nuclear extracts prepared from Drosophila embryos staged at 1.5-4 hr of development and at 3-hr intervals thereafter. The DNA used for binding was a synthetic 33-bp sequence containing the 21-bp, ExollI-resistant sequence, in addition to $6 \mathrm{bp}$ of DNA on each side. As shown in Figure 1a, FTZ-F1 DNA binding activity is observed first in 1.5- to 4-hr-old embryos; the activity then diminishes before reappearing in 13- to 16 -hr embryos, peaking in 16- to 22 -hr embryos. The activity is also observed in extracts of larvae and adults but is hardly detectable in pupal extracts (data not shown), possibly because of proteolysis; the lack of a sharp band in lanes showing larval activity in Figure 1 also suggests that FTZ-Fl is partly degraded in larval extracts. The presence of FTZ-F1 DNA binding activity in 1.5- to 4-hr embryo extracts is correlated with $f t z$ RNA expression in seven stripes. However, the appearance of FTZ-F1 activity in late-stage embryos (predominantly after $16 \mathrm{hr}$ of embryogenesis) and the activity in larvae and adults is not correlated with detectable ftz expression. In Figure $1 \mathrm{~b}$, we show that the binding of FTZ-F1 to DNA is sequence-specific, because formation of the ${ }^{32} \mathrm{P}$-labeled complex is inhibited by an excess of unlabeled binding sequence and not by other DNA sequences. The signal intensities on the autoradiograph in Figure 1A suggest that the level of FTZ-F1 DNA binding activity in 1.5- to 4-hr embryos is apparently low when compared to the activity in 16- to 19-hr and 19- to 22-hr embryos /curiously, this low level is due to use of polyacrylamide as the gel matrix in the gel mobility-shift assay; on agarose gels, the 1.5- to 4-hr activity is as strong as the activity in 16- to 19 -hr embryos; data not shown).

\section{Properties of early and late FTZ-F1}

We refer to the FTZ-F1 DNA-binding activity in 1.5- to 4-hr embryos as early FTZ-Fl and the activity in late embryos, larvae, and adults as late FTZ-F1. The early FTZ-F1-DNA complex migrates slower than the late complex in the gel mobility-shift assay (see Fig. la, "mix" lane), suggesting that early and late FTZ-F1 may differ in size and or charge. Figure 2a shows that the two forms of FTZ-Fl are similar but nonidentical when compared by protease digestion/gel mobility-shift analysis (Marzouki et al. 1986). Extended digestion of early and late FTZ-F1-DNA complexes with chymotrypsin reveals a common chymotrypsin-resistant domain that is still capable of binding to DNA. However, at intermediate stages of proteolysis, some of the partially proteo- 


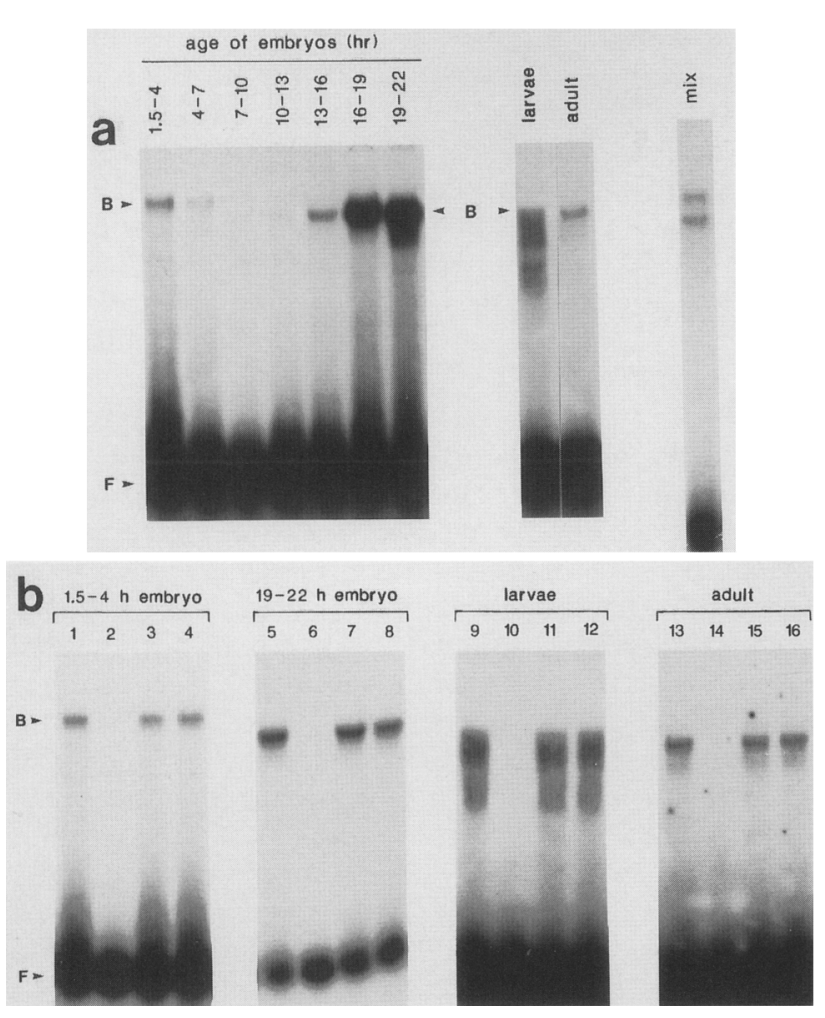

Figure 1. Sequence-specific binding of FTZ-F1 in extracts prepared at progressive stages of development. $|a|$ Autoradiograph of a $4 \%$ polyacrylamide gel showing a gel mobility-shift analysis of protein binding to a 33-bp synthetic FTZ-F1-binding sequence displayed in Fig. 5d, site I). Nuclear extracts of Drosophila embryos staged at $25^{\circ} \mathrm{C}$, first instar larvae, and adults, as indicated, were incubated with ${ }^{32} \mathrm{P}$-labeled DNA and subjected to native PAGE. The amount of extract used from each embryonic stage was normalized, using the DNA content of the nuclear pellet as a reference. (Mix) One microliter of $1.5-$ to $4-\mathrm{hr}$ extract and $1 \mu \mathrm{l}$ of a $1: 40$ dilution of $12-$ to $24-\mathrm{hr}$ extract in a standard gel mobility-shift assay. (B) Bound protein-DNA complex; (F) free DNA. (b) Specificity of protein-DNA complexes. Standard gel mobility-shift analysis of extracts staged, as indicated, in the presence of the following unlabeled competitor DNAs. (Lanes 2, 6, 10, and 14) 20-fold molar excess of specific binding site; (lanes $3,7,11$, and 15) 20-fold molar excess of a 44-bp heat shock control element (Wu et al. 1987); (lanes 4, 8, 12 , and 16) 100-fold mass excess of E. coli DNA fragmented by micrococcal nuclease cleavage to an average size of $500 \mathrm{bp}$. Lanes 1, 5, 9, and 13 have no competitor DNA.

lyzed, early and late FTZ-F1-DNA complexes have a common mobility, whereas other complexes show different mobilities, suggesting a distinct difference between the two forms of FTZ-F1 outside of the DNAbinding domain. Further comparison of the interaction of early and late FTZ-Fl with the binding sequence indicates that the two forms cannot be distinguished by DNase I protection and methylation interference assays (Fig. 2b-d). These results, combined with immunological analysis discussed below, suggest that the DNAbinding domains of early and late FTZ-F1 are similar, if not identical.

\section{Purification of FTZ-F1 from late embryos}

To study the properties of FTZ-F1, we have purified the factor to homogeneity from late stage (12- to 24-hr-old) Drosophila embryos. Although roughly equivalent levels of activity can be found in 1.5- to 4-hr-old embryos, logistical difficulties involved in harvesting kilogram quantities of embryos staged within such a narrow time window have precluded an attempt to purify early FTZ-F1. Nuclear extracts of late-stage embryos were chromatographed sequentially on heparin-Sepharose, sequence-specific DNA-Sepharose, and ion-exchange Mono S (Pharmacia) columns. Figure 3a shows the major polypeptide that eluted from the affinity column has an apparent molecular mass of $95 \mathrm{kD}$ as measured by SDSPAGE. The $95-\mathrm{kD}$ polypeptide was purified to $\sim 95 \%$ homogeneity by further chromatography on a Mono $\mathrm{S}$ column. Figure 3B shows that the DNase I and ExoIII protection patterns produced by affinity-purified, late FTZ-F1 are indistinguishable from the patterns produced by the late FTZ-F1 activity in crude extracts. As shown in Table $1, \sim 2 \mu \mathrm{g}$ of 25,000 -fold purified factor was obtained from $870 \mathrm{mg}$ of nuclear protein (1.25-kg embryos), with a final yield of $\sim 6 \%$. We have tried to confirm the size of FTZ-F1 independently by photo-affinity labeling, by Southwestern analysis, or by analysis of DNA binding activity after renaturation of protein eluted from SDS-polyacrylamide gel slices, but have not been successful in eliciting activity from the protein, even after repeated attempts.

\section{Immunological comparison of early and late FTZ-F1}

Because it was not feasible to collect sufficient numbers of 1.5- to 4-hr embryos to purify early FTZ-F1, we studied the early factor with mouse polyclonal antibodies raised against purified late factor. As shown by protein gel blot analysis in Figure 4a, anti-late FTZ-F1 serum reacts with the $95-\mathrm{kD}$ polypeptide in a DNA affinity-purified fraction containing the late factor. However, the antiserum was unable to detect (on protein gel blots) the late factor in crude extracts or after heparinSepharose chromatography. We therefore tested serum reaction with late and early FTZ-F1 in crude extracts using the gel mobility-shift technique. Figure $4 \mathrm{~b}$ (left) shows that anti-late FTZ-Fl serum inhibits the formation of the late FTZ-F1-DNA complex, as might be expected; no effect is observed with preimmune serum. More importantly, the serum also inhibits the formation of the early FTZ-F1-DNA complex (right). These results indicate that early and late FTZ-F1 have common antigenic determinants. We have also attempted to stain fixed Drosophila embryos with the anti-late FTZ-F1 serum but have been unable to detect any signals, possibly because of the low titer of the antiserum.

\section{FTZ-F1 binds to multiple sites upstream of, and within, the $\mathrm{ftz}$ gene}

We screened for other FTZ-F1-binding sites in the $f t z$ gene region by further binding experiments, using af- 

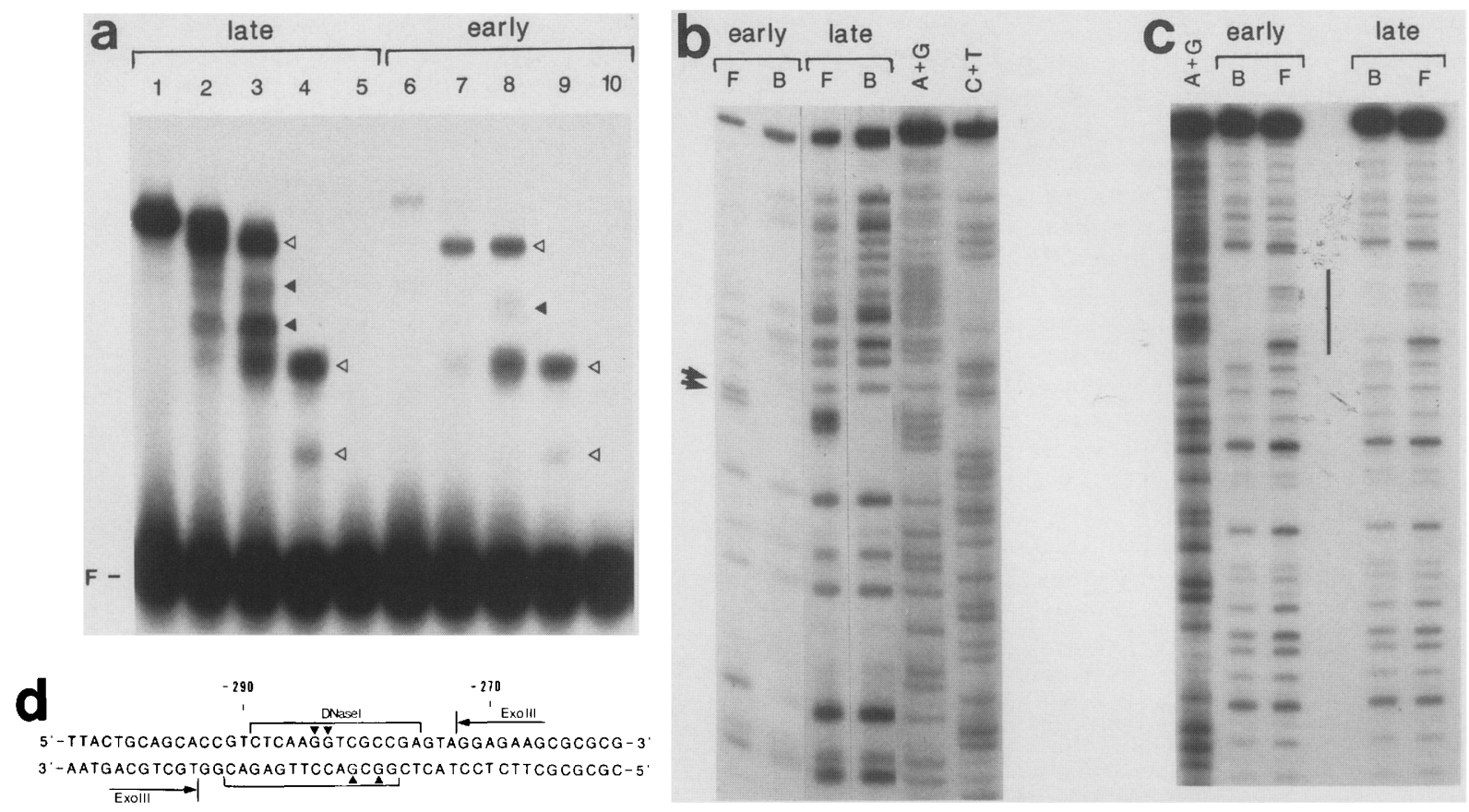

Figure 2. Comparison of early and late forms of FTZ-F1. (a) Protease digestion. Gel mobility-shift analysis of 1.5- to 4-hr (early; lanes 6-10) and 12- to 24-hr (late; lanes 1-5) FTZ-F1-DNA complexes treated with chymotrypsin at $25^{\circ} \mathrm{C}$ for 0 sec (lanes 1 and 6), 15 sec (lanes 2 and 7), 1 min (lanes 3 and 8), and 10 min (lanes 4 and 9). Lanes 5 and 10 show 1-min protease digestions in the presence of 100-fold molar excess unlabeled binding site. Chymotrypsin digestion products of early and late FTZ-F1-DNA complexes that have similar mobilities are noted by open arrowheads; solid arrowheads denote complexes having dissimilar mobilities. Comparison of lane 6 with lanes 7-9 indicates that the apparent inhibition or destabilization of the early FTZ-F1-DNA complex during native PAGE is relieved after protease digestion. $(B)$ Methylation interference analysis. Autoradiograph of a sequencing gel showing chemical cleavage at sites of G methylation on the upper strand of a 113-bp DdeI-Nrul fragment (positions -362 to -249 of the $f t z$ gene). Arrows indicate the two fragments missing from the overall cleavage pattern in the lanes containing DNA bound to early or late FTZ-F1 $|B|$; the same fragments are enriched in the lanes containing unbound DNA $|F|$. The results imply that methylation at either of the two $G$ residues interferes with the stability of the FTZ-F1-DNA complex. Lanes $A+G$ and $C+T$ show chemical cleavage of free DNA at those residues. (c) DNase I protection analysis. Autoradiograph of an $8 \%$ sequencing gel showing sequences on the upper strand of the DdeI-NruI fragment that are protected from partial DNase I cleavage by bound early and late FTZ-F1. The vertical line indicates the span of the DNase I footprint. Lane A + G denotes chemical cleavage of free DNA at those residues. (d) Summary of DNase I, ExoIII, and methylation interference analysis on upper and lower strands of the binding site common to early and late FTZF1. The horizontal lines bracket sequences protected from DNase I cleavage by early and late FTZ-F1 on the upper strand; only late FTZ-F1 was footprinted on the lower strand. $(\mathbf{\Lambda}, \mathbf{\nabla}) \mathrm{G}$ residues that inhibit the formation of the early and late FTZ-F1-DNA complex when methylated; data not shown for the lower strand. Vertical bars denote the positions of resistance $(-273$ to -293$)$ to ExoIII digestion in the direction of the arrows of early and late factor (Fig. 3b, data not shown).

finity-purified late FTZ-F1 protein. An XbaI-Sall segment of the $f t z$ gene (positions -2450 to +580 ) that includes the neurogenic element was cleaved into smaller fragments by $D$ deI restriction digestion. Without further separation, the set of fragments was labeled with ${ }^{32} \mathrm{P}$, and the ability of the fragments to bind to FTZ-F1 was analyzed by the gel mobility-shift technique. As is shown in Figure 5, a and b, binding of the factor to the labeled fragments results in the appearance of three distinct protein-DNA complexes and the corresponding depletion of three of the original set of DdeI restriction fragments (Fig. 5a, lane 2). All three gel mobility-shift complexes are specific, as the binding to the labeled DNA is decreased by competition with an excess of the original, unlabeled binding sequence (Fig. 5a, lane 3). A similar screen of $6.2 \mathrm{~kb}$ of the Antennapedia gene (between two EcoRI sites at -4.2 and $+2.0 \mathrm{~kb}$ ) did not re- veal the presence of any FTZ-F1-binding sites /data not shown).

Sequence inspection of the DdeI fragments that bound to the late FTZ-Fl revealed three other sequences (sites II, III, and IV) that are homologous to the original binding sequence (site I), located between positions -293 and -273 . As shown in Figure 5c, sites II and III are located within the $f t z$-coding region, whereas site IV is located within the zebra element, $\sim 140 \mathrm{bp}$ downstream of site I. The relative affinities of the four sites for late FTZ-F1 were studied by the ability of each unlabeled site to compete with ${ }^{32} \mathrm{P}$-labeled site I in the gel mobility-shift assay. As shown in Figure 5e, sites I, II, and III compete with equal efficiency, whereas site IV competes with $\sim 10$-fold lower efficiency. Similar competition experiments using 1.5- to 4-hr extracts as a source for early FTZ-F1 show that early FTZ-F1 also 
Figure 3. Purification and properties of FTZ-F1 from late embryos. (a) SDS-PAGE $(10 \%$ gel) analysis at each step of purification. The lanes show silverstained proteins in the nuclear extract (crude), heparin-Sepharose, first-pass affinity column, and Mono S fractions, as indicated. (The second-pass affinity column fraction not shown contained proteins similar to, but more concentrated than, the first-pass fraction.) (Lane 1) 0.17 units; (lane 2) 0.39 units; (lane 3) 380 units, (lane 4) 370 units of late FTZ-F1. One unit is defined as the amount of activity that binds to 1 fmole of labeled binding site in a gel mobility-shift assay. The sizes of the molecular weight markers are indicated. $(b \mid$ Nuclease protection analysis using purified late FTZ-F1. To show upper strand protection (left), the DdeI-NruI fragment (see Fig. 5c) was $5^{\prime}$-end-labeled at the DdeI site and incubated with late embryo nuclear extract (NE), buffer only $(-)$, or first-pass affinity-purified FTZ-F1 $\mid+1$, prior to digestion with ExoIII or DNase $\mathrm{I}$, as indicated, and separation of the fragments on an $8 \%$ sequencing gel. To show lower-strand protection (right), a HaeIII-NruI fragment (positions -312 to -249 ) was 5 '-end-labeled at the NruI site, incubated with protein or buffer samples, and subjected to nuclease cleavage and gel electrophoresis as noted above. Lanes $G, A+G$, and $C+T$ show chemical cleavage of free DNA at those residues.
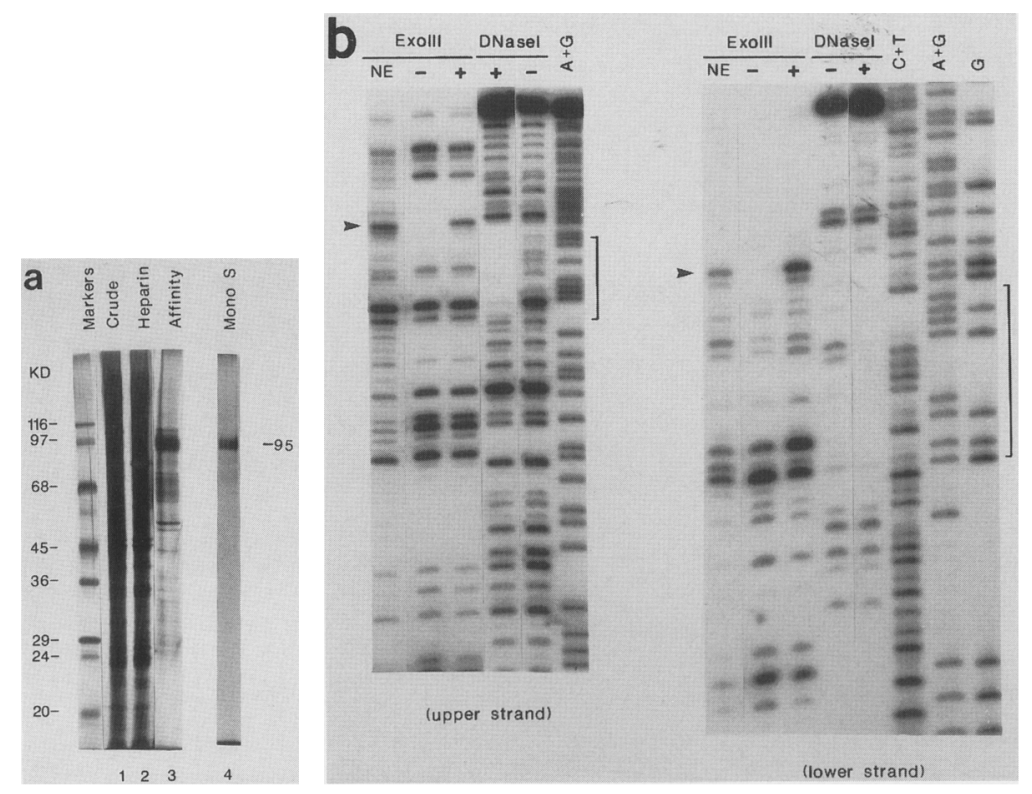

binds to the four sites with similar relative affinities (data not shown). The three strong binding sites define a consensus FTZ-F1-binding sequence: PyCAAGGPyC$\mathrm{PuCCPu}$ (Fig. 5d), of which eight nucleotides form an invariant core. The fourth, weaker binding site matches the invariant core of the consensus sequence at six of eight nucleotide positions. It should be noted that the four binding sites identified so far do not exclude the possibility that FTZ-F1 could also bind to other, possibly divergent sequences within these fragments.

\section{Effects of mutations in the FTZ-F1-binding sequence}

To determine the contribution of FTZ-F1 to $f t z$ expression in vivo, the zebra element was mutated at FTZ-F1binding site I. As indicated in Figure 6a, nucleotides that closely contact FTZ-Fl, as identified by methylation in-

Table 1. Purification of FTZ-F1

\begin{tabular}{lccccc}
\hline Fraction & $\begin{array}{l}\text { Total } \\
\text { protein } \\
\left(\mu \mathrm{g} \times 10^{-3}\right)\end{array}$ & $\begin{array}{l}\text { Sp. act. } \\
(\mathrm{U} / \mu \mathrm{g})\end{array}$ & $\begin{array}{l}\text { Total } \\
\text { units }^{\mathrm{a}} \\
\left(\times 10^{-3}\right)\end{array}$ & $\begin{array}{l}\text { Yield } \\
(\%)\end{array}$ & $\begin{array}{l}\text { Purification } \\
\text { factor }\end{array}$ \\
\hline $\begin{array}{c}\text { Nuclear } \\
\text { extract }\end{array}$ & 870 & 0.57 & 500 & 100 & 1 \\
$\begin{array}{c}\text { Heparin- } \\
\quad \text { Sepharose }\end{array}$ & 150 & 4.3 & 640 & 129 & 7.5 \\
$\begin{array}{c}\text { Affinity 1 } \\
\text { Affinity 2 }\end{array}$ & 0.025 & 6,800 & 170 & 34 & 12,000 \\
Mono S & 0.010 & 11,000 & 105 & 21 & 18,000 \\
\hline
\end{tabular}

al unit is defined as the amount of activity that binds to one fmole of labeled binding sequence in a gel mobility-shift assay.

bThis amount of the $95-\mathrm{kD}$ proteins is consistent with that calculated $(2.8 \mu \mathrm{g})$ for 28,000 units of FTZ-F1 activity, assuming that one FTZ-F1 molecule binds to one molecule of the binding sequence. terference analysis, were chosen as candidates for sitedirected mutagenesis. Two different mutations, a 2-and a 4-base substitution, were constructed, in the event that a new factor-binding sequence was created by one of the mutations. In Figure 6b, gel mobility-shift analysis shows that a ${ }^{32} \mathrm{P}$-labeled restriction fragment containing either the 2- or the 4-base substitution mutation is unable to interact in vitro with early or late FTZ-F1 in crude extracts. In addition, no new complexes are detected by the gel mobility-shift analysis, indicating that a binding site for another factor present in the extracts was not inadvertently created by the mutations. From competition experiments similar to those shown in Figure $5 \mathrm{e}$, we estimate that the binding affinity of early and late FTZ-Fl for both mutated binding sites is reduced by $>100$-fold (data not shown).

To test whether the mutations in FTZ-F1-binding site I could affect the ability of the zebra element to generate stripes in vivo, wild-type and mutant zebra elements were joined to the $l a c Z$ gene and introduced into flies by P-element-mediated germ line transformation. As indicated above, FTZ-F1-binding site I was mutated, leaving site IV untouched; binding site IV has a 10 -fold weaker interaction with the factor and, in addition, overlaps the binding site of another nuclear factor (J.L. Brown and C. $\mathrm{Wu}$, unpubl.). Binding sites II and III, which are located within the $f t z$ protein-coding sequence, are not contained in the zebra element. Hence, the wild-type zebra-lac $Z$ construct, as originally defined by Hiromi et al. (1985), carries two (of four) FTZ-F1-binding sites, whereas the mutated zebra-lac $Z$ constructs carry a single, weak FTZ-F1-binding site.

Multiple independent transformant lines carrying the wild-type and mutant zebra-lac $Z$ constructs, derived 
from different transformed parents, were established as homozygous stocks. The patterns of $\beta$-galactosidase $(\beta$ gal) gene expression in embryos collected from each transformant line were examined by staining with X-gal and by indirect immunohistochemical staining; the staining of wild-type and mutant transformant embryos was conducted under the same conditions. As reported previously (Hiromi et al. 1985), the expression of zebralac $Z$ constructs is undetectable at the cellular blastoderm stage, presumably because these constructs lack

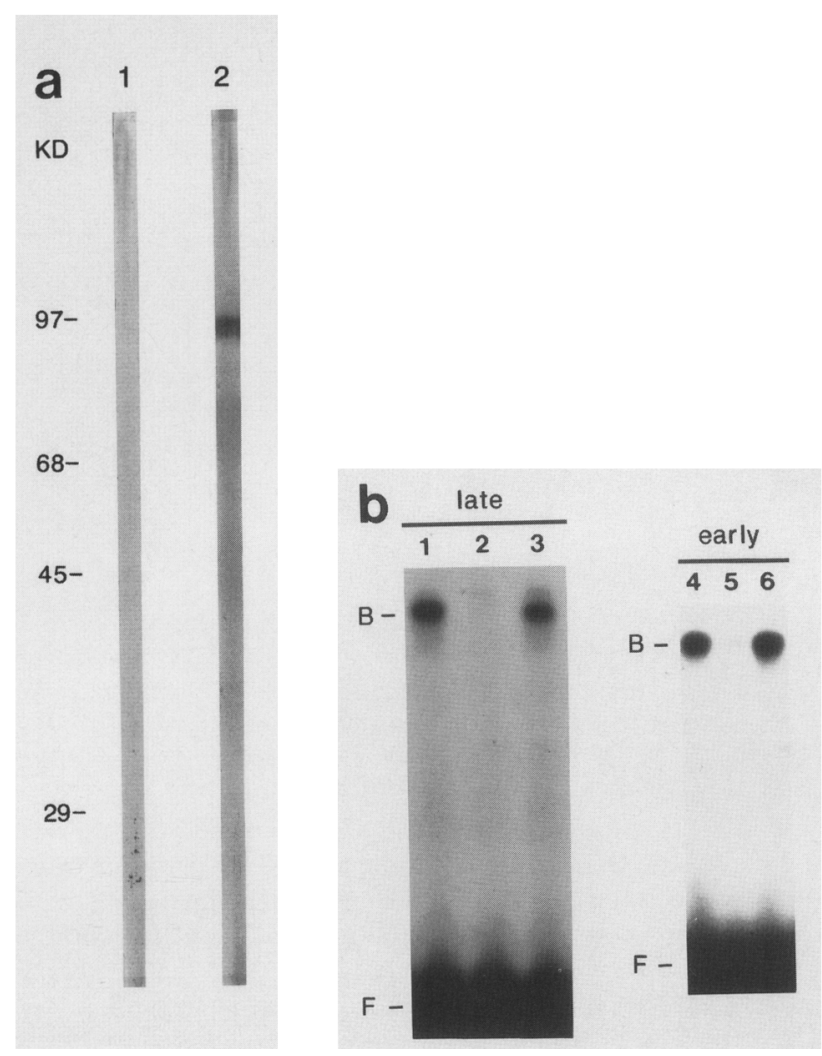

Figure 4. Immunological comparison of early and late FTZ-F1. (a) Western blot analysis of late FTZ-F1. A 1 : 1000 dilution of anti-late FTZ-F1 (polyclonal) serum (lane 2) or preimmune serum (lane 1) was reacted with a nitrocellulose strip onto which was transferred (after SDS-PAGE) $20 \mathrm{ng}$ of protein from the late embryo FTZ-F1 fraction of the first-pass affinity column. The strips were incubated with a $1: 1000$ dilution of affinity-purified goat anti-mouse $\operatorname{IgG}$ conjugated to alkaline phosphatase and stained with color development substrate (Promega). The immune serum stains a band of $95 \mathrm{kD}$. The sizes of the molecular weight markers are indicated. $(B)$ Antilate FTZ-Fl serum reacts with early and late FTZ-F1. Autoradiograph of a gel mobility-shift assay showing that anti-late FTZ-F1 serum inhibits the DNA binding activity of FTZ-F1 in early (1.5- to $4-\mathrm{hr}$ ) and late (12- to $24-\mathrm{hr}$ ) embryo extracts, as indicated. Each reaction contained $1 \mu l$ of $1: 2$ dilution of early extract or $1 \mu \mathrm{l}$ of $1: 10$ dilution of late extract, $6 \mu \mathrm{l}$ of PBS, $1 \mu 1$ of a mixture of $1 \mathrm{mg} / \mathrm{ml}$ poly[d(I-C)/poly[d(I-C)] and $3 \mathrm{pmole} / \mathrm{ml}$ labeled binding site, $1 \mu \mathrm{l}$ of $5 \mathrm{mg} / \mathrm{ml} \mathrm{BSA}$, and $1 \mu \mathrm{l}$ of a $1: 10$ dilution of immune serum (lanes 2 and 5), preimmune serum (lanes 3 and 6), or no serum (lanes 1 and 4). Samples were incubated for $1 \mathrm{hr}$ at $25^{\circ} \mathrm{C}$ before polyacrylamide (lanes 1-3) or agarose (lanes 4-6) gel electrophoresis. (B) Bound; (F) free DNA. the upstream enhancer element, but is detectable shortly thereafter, during extension of the germ band (embryonic stage 9-10), when the $\beta$-gal protein has accumulated to sufficient levels. The pattern of wild-type zebra element-mediated lac $Z$ expression in germ-band elongation-stage embryos is shown by immunohistochemical staining in Figure 7, a and c. The staining pattern showing seven stripes in the mesoderm is in concordance with the pattern obtained with the original zebra-lacZ construct (Hiromi et al. 1985; Hiromi and Gehring 1987). Also in concordance with the original observations and unlike the even distribution of native $f t z$ protein in the seven stripes, the expression of $\beta$-gal in different stripes is unequal: The anterior three stripes are weak relative to the posterior three stripes, and stripe 1 is especially weak.

Figure $7, \mathrm{~b}$ and $\mathrm{d}$, shows the immunohistochemical staining pattern of embryos carrying the zebra-lac $Z$ fusion gene mutated at FTZ-F1-binding site I by the 4-base substitution. Relative to the wild-type pattern, the mutant pattern shows strong, roughly equivalent staining in stripes $4,5,7$, and weaker, but detectable, staining in stripes 2,3 , and 6 ; there is no detectable staining of stripe 1. A similar staining pattern is obtained with the 2-base substitution mutant construct (data not shown). This decrease in staining of stripes $1,2,3$, and 6 is also evident in later, germ-band retraction-stage embryos carrying the mutant construct (data not shown).

In addition to the changes in relative stripe intensity, there is some change in the absolute intensity of the stripes. This is observed more easily by monitoring the appearance of stripes, as detected by $\beta$-gal activity. Under otherwise identical conditions, embryos carrying the mutant construct require a longer reaction time with the substrate X-gal, to reach a level of staining that is equivalent to the staining in embryos carrying the wild-type construct (data not shown). Hence, it appears the FTZ-F1 binding is required for the proper levels of activation of all stripes and especially of stripes 1, 2, 3, and 6.

\section{Discussion}

Biochemical studies have resulted in the isolation of a number of Drosophila transcription factors involved in the regulation of developmental control genes (e.g., Biggin and Tjian 1988; Perkins et al. 1988; Soeller et al. 1988). Using a DNA binding assay, we have purified a DNA-binding protein from Drosophila embryos, FTZ-F1, which binds specifically to four similar sequences, two within the $f t z$ zebra element and two within the $f t z$ protein-coding sequence. Germ line transformant embryos carrying a zebra element-lac $Z$ construct mutated at an FTZ-Fl-binding site show decreased lacZ expression, suggesting that FTZ-F1 functions as a transcriptional activator of the $f t z$ gene.

The decreased lac $Z$ expression in stripes 1, 2, 3, and 6 could be due to several mechanisms. FTZ-F1 could simply be active predominantly in these four stripes. Alternatively, FTZ-F1 could be active in all seven stripes, and other activators, present in stripes 4,5 , and 7 , might 

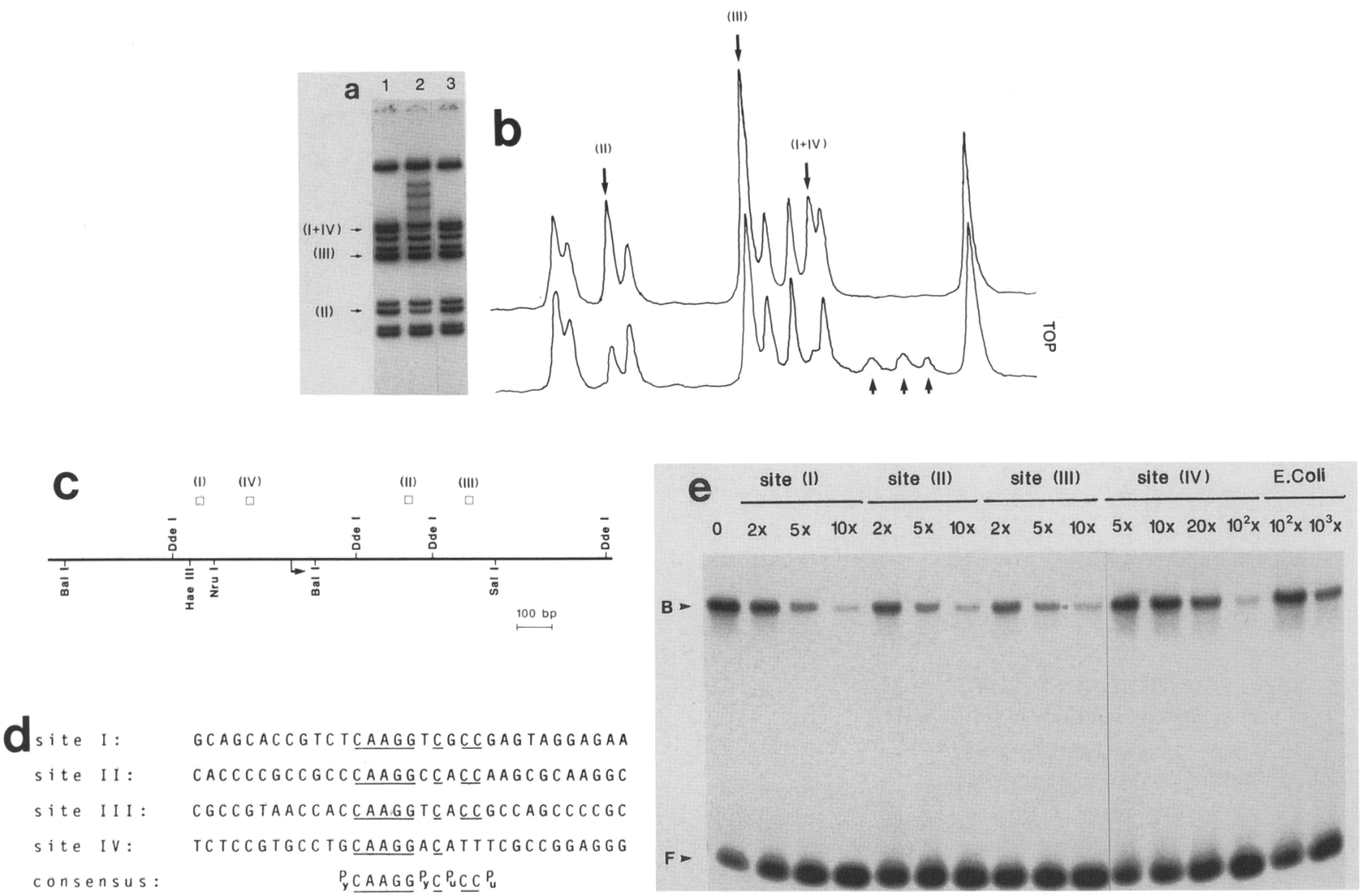

Figure 5. FTZ-F1 has multiple binding sites on the $f t z$ gene. (a) Gel mobility-shift analysis on DdeI restriction fragments of a $X b a I-S a l I$ (positions -2.45 to $+0.58 \mathrm{kbp}$ ) segment of the $\mathrm{ftz}$ gene (Laughon and Scott 1984; Hiromi et al. 1985). $0.8 \mathrm{fmole}$ of the complete mixture of $5^{\prime} 32 \mathrm{P}$-end-labeled fragments was used for the gel mobility-shift assay. (Lane 1) No FTZ-F1; (lane 2) about 1 ng of first-pass affinity column purified FTZ-F1; (lane 3) $4 \mathrm{ng}$ of the same FTZ-F1 + 50 fmoles (63-fold molar excess) of the unlabeled 33-bp binding site. Three restriction fragments depleted as a result of the binding of FTZ-F1 are indicated by arrows. I-IV relate four FTZ-Fl-binding sites to the restriction fragments. Similar analyses not shown were performed with HinfI, HaeIII, HpaII, and $B a n I+B a l l+B s t$ EII. $(b)$ Densitometer scan of $a$, lanes 1 and 2 (upper and lower tracings, respectively). Arrowheads pointing upward indicate the three new gel mobility-shift complexes. Arrows pointing downward indicate DNA fragments that are depleted when bound to FTZ-F1. The top of the gel is indicated. (c) Restriction map showing locations of the FTZ-F1-binding sites ( $\square$ ), numbered I-IV. The start site and direction of transcription is indicated by the arrow. The location of the start site was reanalyzed and found to be 70 nucleotides upstream of the first methionine codon, in agreement with the position reported by Hiromi et al. (1985); P. Becker, J. Tamkun, M. Scott, and C. Wu (unpubl.). (d) Sequence comparison of the four FTZ-F1-binding sites. The derived consensus sequence is underlined, as are the sequences identical to the consensus in the four sites. The positions of the $5^{\prime}$ cytosine at the start of the consensus at each site are, $-287,+331,+506$, and -144 , respectively on the $f t z$ gene. $(e)$ Relative affinities of FTZ-F1-binding sites. Two microliters of 12 - to $24-\mathrm{hr}$ embryo nuclear extract was incubated with $0.5 \mathrm{pmole} / \mathrm{ml}$ of ${ }^{32} \mathrm{P}$-labeled binding site $\mathrm{I}$ in a $10 \mu \mathrm{l}$ standard gel mobility-shift reaction. The reactions contained the following unlabeled competitor DNAs: site I, site II, site III, site IV, and E. coli DNA, at the indicated molar ratios (or mass ratios, for E. coli DNA). Similar results were obtained using 1.5- to 4-hr embryo extracts.
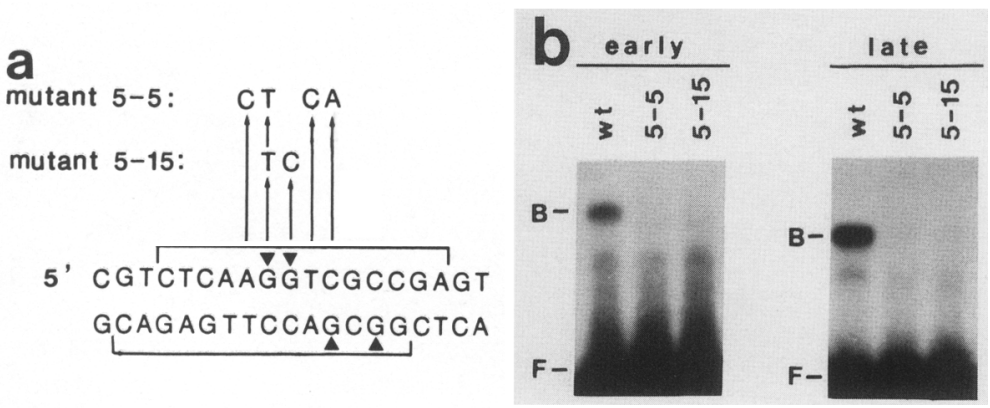

Figure 6. Mutations within the FTZ-F1-binding site disrupt the FTZ-F1-DNA complex in vitro. $(a)$ Sequence of the FTZ-F1-DNase I footprint, as in Fig. 2D. Mutants 5-5 and 5-15 are 4- and 2-base substitutions engineered into the $f t z$ zebra element by site-directed mutagenesis. The site-directed mutagenesis procedure was performed according to a commercial protocol (Amersham) using a 26-base synthetic oligonucleotide spanning the FTZ-F1 binding site. $|b|$ Gel mobility-shift analysis of the mutant binding sites. A 5 ' 32P-end-labeled, 123-bp BanI-BanI fragment (positions -199 to -322 ), containing the indicated wild-type $(\mathrm{wt})$ and mutant $(5-5$ and 5-15) binding sites, was incubated with $1.0 \mu \mathrm{l}$ of early (1.5to 4-hr) or late (16- to 22-hr) embryo extracts in a $10-\mu l$ gel mobility-shift reaction. Samples were analyzed by $1 \%$ agarose gel electrophoresis. 

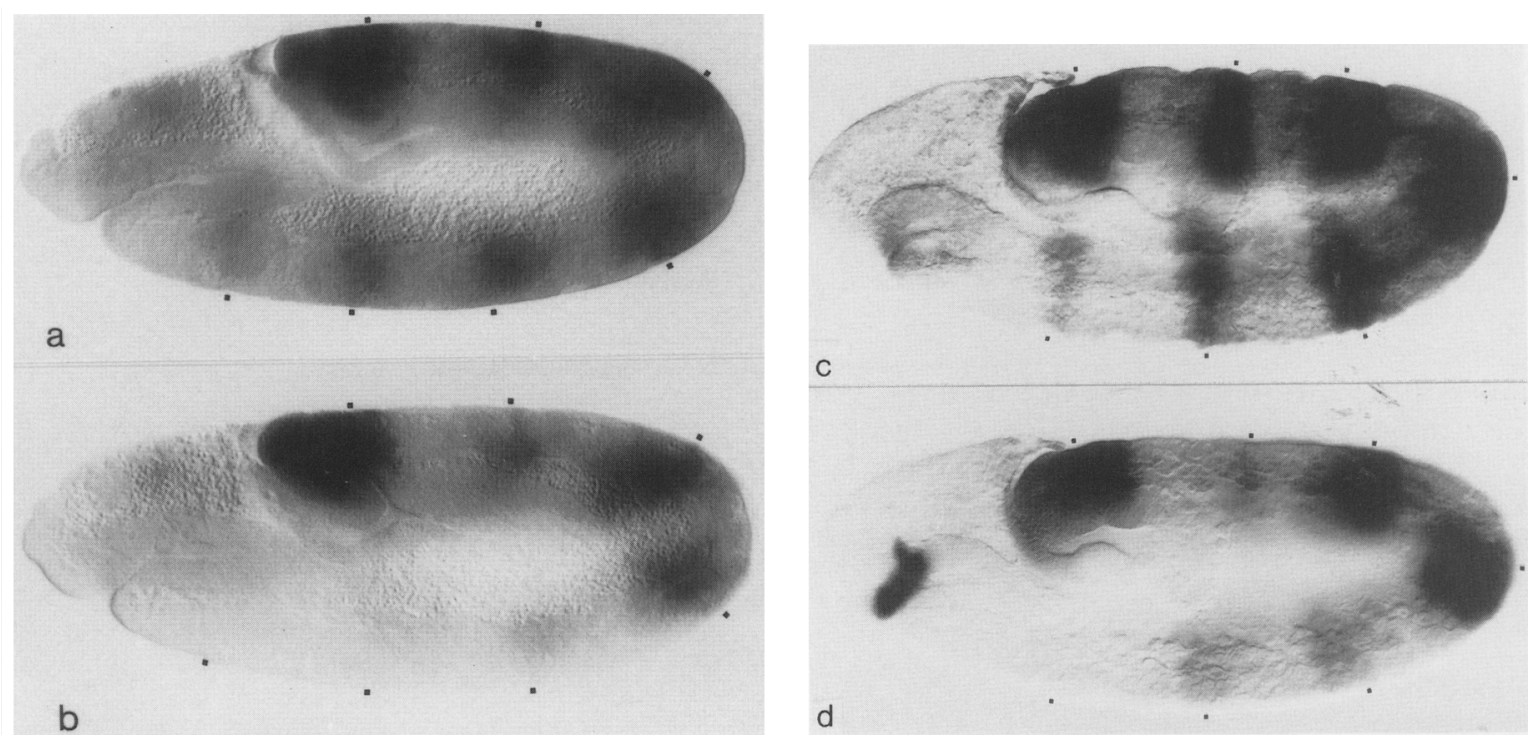

Figure 7. lacZ expression detected by immunohistochemical staining in embryos transformed by wild-type and mutant zebra element-lac $Z$ fusion constructs. ( $a$ and $c$ ) lac $Z$ expression from the wild-type zebra element fusion construct, showing seven graded stripes of $\beta$-gal expression in a stage- 11 and a stage- 10 embryo, respectively. ( $b$ and $d) l a c Z$ expression from the zebra element mutated by the 4-base substitution at FTZ-Fl-binding site I. The staining pattern of a stage-11 and a stage-10 embryo from two different mutant lines is shown. The apparent increase in the staining of stripe 7 in the embryo shown in $b$ is an anomaly. $(d)$ The mutant line $\mathrm{F}_{6}$ also shows ectopic head staining at the stomodeal invagination.

compensate for the loss of the FTZ-F1-DNA interaction in embryos carrying the mutant construct. A knowledge of the distribution of active FTZ-Fl during early embryogenesis is required to distinguish between these possibilities. It also remains possible that the in vivo effects of the mutations in FTZ-F1-binding site I are caused by the binding of an adventitiously recruited transcription factor, rather than by the loss of FTZ-F1 binding. However, we believe that this possibility is unlikely, because no binding to either the 2- or the 4-base mutant construct is detected in vitro and because both mutant constructs (which differ at four nucleotide positions) caused the same alterations in zebra-lacZ expression.

A recent analysis by sequential deletions of the $f t z$ zebra element in the zebra-lac $Z$ fusion gene suggests that the element is comprised of multiple activator and repressor elements (Dearolf et al. 1989). The staining patterns of embryos carrying the constructs relevant to our study $\left(5^{\prime}\right.$ truncations to positions -359 and -239 ; $3^{\prime}$ truncations to -272 and -347 ) do not resemble the staining pattern of embryos carrying our mutant constructs (2- and 4-base substitution mutations of FTZ-F1binding site I, located between -293 and -273 ). Because multiple regulatory elements are contained within the zebra element, deletions that eliminate more than one cis-regulatory element and change potential stereospecific alignments between neighboring elements will mask the contribution of any individual element. Our substitution mutations in FTZ-F1-binding site I, which presumably affect only one transcription factor, reveal an unexpectedly specific pattern of activity for a transcriptional activator that acts on the zebra element.

Factors that bind in vitro to the $f t z$ upstream enhancer element (located between positions -6.1 and $-3.5 \mathrm{~kb}$ ) have been reported recently by Harrison and Travers (1988). By inspection of their published sequence of the enhancer element, we have found three potential FTZ-F1-binding sites, which are highly similar to the consensus FTZ-F1-binding sequence. These three sequences match the invariant core of the consensus at six or seven of eight positions, and it is interesting to speculate that they may also interact with FTZ-F1.

The existence of early and late forms of FTZ-F1, which are similar but not identical, is intriguing. Only early FTZ-F1 activity is correlated in time with the expression of $f t z$ gene in seven stripes. Late FTZ-F1 activity is roughly correlated with the general repression of $f t z$ transcription from late embryos to adult. We speculate that late FTZ-F1 may contribute to the general repression of $f t z$ gene after $15 \mathrm{hr}$ of development. Alternatively, the functions of late FTZ-F1 could be completely unrelated to the $f t z$ gene but could involve other, as yet unknown genes.

The altered pattern of $1 a c Z$ expression that we have observed in embryos carrying the mutated zebra-lac $Z$ constructs is novel. Among the maternal and zygotic genes known to affect $f t z$ expression, none appears to cause a change in the pattern of stripes that closely resembles the expression pattern of our mutated constructs. Only the expression pattern of a zebra elementlac $Z$ construct in embryos hemizygous for a hypomorphic runt allele, run ${ }^{Y E 96}$ (Hiromi and Gehring 1987), shows a loss of stripes 3 and 6 , and these stripes are among those affected in our mutant zebra-lac $Z$ construct. It is possible that early FTZ-F1 mediates the influence of run on $\mathrm{ftz}$.

The combined early and late activities of FTZ-F1 sug- 
gest that the FTZ-F1 gene may not be found among the more than 20 loci identified by genetic screens for embryonic zygotic lethal mutations that cause specific alterations in the segmented pattern of the cuticle (Nüsslein-Volhard and Wieschaus 1980; Jürgens et al. 1984; Nüsslein-Volhard et al. 1984; Wieschaus et al. 1984). The FTZ-F1 gene could be represented among the remaining 120 loci that have a more unspecific cuticular phenotype. Alternatively, the gene may have been missed completely in screens for embryonic visible lethal mutations, as maternal contributions to the egg may mask embryonic lethality or phenotypes (e.g., Perrimon et al. 1984, 1989; Perrimon and Mahowald 1988). As the cloning and analysis of the FTZ-F1 gene progresses, it should be interesting to determine the phenotypes associated with mutations in the locus.

\section{Experimental procedures}

\section{Preparation of extracts}

Embryos $0-3 \mathrm{hr}$ and $0-2.5 \mathrm{hr}$ old were collected from a mass population of Drosophila melanogaster (Oregon R, P2) reared at $25^{\circ} \mathrm{C}$. The stages of development were checked by microscopy, and the embryos were aged at $25^{\circ} \mathrm{C}$ to generate the indicated stages. Embryos were dechorionated in $50 \%$ Clorox $/ 0.25 \%$ Triton X-100 for $3 \mathrm{~min}$, washed extensively, and frozen at $-70^{\circ} \mathrm{C}$. All subsequent procedures were performed at $4^{\circ} \mathrm{C}$. Typically, 10 grams of embryos were homogenized in a Dounce homogenizer in $40 \mathrm{ml}$ of $1 \mathrm{M}$ sucrose/solution I [10 mM HEPES (pH 7.9), $10 \mathrm{~mm} \mathrm{KCl}, 3 \mathrm{~mm} \mathrm{MgCl}, 0.5 \mathrm{~mm}$ DTT, $0.5 \mathrm{~mm}$ phenylmethylsulfonyl fluoride (PMSF), $5 \mu \mathrm{g} / \mathrm{ml}$ leupeptin, $2 \mu \mathrm{g} / \mathrm{ml}$ pepstatin, $0.75 \mu \mathrm{g} / \mathrm{ml}$ aprotinin]. The homogenate was filtered through two layers of nylon cloth $(63-\mu \mathrm{m}$ mesh), the mesh was washed with $40 \mathrm{ml}$ of $1 \mathrm{M}$ sucrose/solution I, and the combined filtrate was centrifuged for $10 \mathrm{~min}$ at $400 \mathrm{~g}$ to remove debris and unbroken cells. Nuclei were pelleted from the supernatant by centrifugation for $10 \mathrm{~min}$ at $4500 \mathrm{~g}$. The pellet was resuspended in $10 \mathrm{ml}$ of $1 \mathrm{M}$ sucrose/solution $\mathrm{I}$; each of $5 \mathrm{ml}$ was layered on a 26-ml gradient of 1.0-1.7 $\mathrm{M}$ sucrose/solution I, and nuclei were pelleted by centrifugation for $15 \mathrm{~min}$ at $17,000 \mathrm{~g}$ in a swinging bucket rotor. The pellet was resuspended in 3 volumes of solution II [10 mM HEPES ( $\mathrm{pH} 7.9$ ), $0.4 \mathrm{M} \mathrm{NaCl}, 3 \mathrm{~mm} \mathrm{MgCl}_{2}, 0.5$ mM DTT, $5 \%$ glycerol, with protease inhibitors as above] and was extracted at $4^{\circ} \mathrm{C}$ for $30 \mathrm{~min}$ before centrifugation at $100,000 \mathrm{~g}$ for $50 \mathrm{~min}$. The supernatant was dialyzed in solution III [20 mM HEPES (pH 7.9), $50 \mathrm{~mm} \mathrm{NaCl}, 0.5 \mathrm{~mm}$ DTT, $0.5 \mathrm{~mm}$ PMSF, 20\% glycerol], clarified by centrifugation, frozen in liquid $\mathrm{N}_{2}$, and stored at $-70^{\circ} \mathrm{C}$. Extracts of first instar larvae and adults were prepared essentially as above. The protein concentration of the extracts was $\sim 1.5 \mathrm{mg} / \mathrm{ml}$.

\section{Gel mobility-shift analysis}

The 33-bp FTZ-Fl-binding site was prepared from complementary synthetic oligonucleotides that were gel-purified, annealed, and labeled with polynucleotide kinase and $\left[\gamma^{-32}\right]$ ATP.

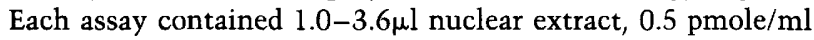
labeled binding site, $5 \mathrm{mg} / \mathrm{ml}$ BSA, $0.1 \mathrm{mg} / \mathrm{ml}$ poly $[\mathrm{d}(\mathrm{I}-$ Cll $\cdot$ poly[d(I-C)], $15 \mathrm{~mm}$ Tris- $\mathrm{HCl}(\mathrm{pH} 7.4), 100 \mathrm{~mm} \mathrm{NaCl}, 1 \mathrm{~mm}$ EDTA, and $5 \%$ glycerol in a final volume of $10 \mu$ l. Samples were incubated for $30 \mathrm{~min}$ at $25^{\circ} \mathrm{C}$ before electrophoresis at $4^{\circ} \mathrm{C}$ on a $4 \%$ polyacrylamide gel in $5 \%$ glycerol, $2 \times$ TBE buffer (Maniatis et al. 1982), or on a $1 \%$ agarose gel in $0.5 \times$ to $1 \times \mathrm{TBE}$ buffer.

\section{Protease digestion/gel mobility-shift analysis}

Early or late embryo extracts were incubated with labeled binding site in standard gel mobility-shift conditions prior to addition of $1 \mu \mathrm{l}$ of $0.1 \mathrm{mg} / \mathrm{ml}$ chymotrypsin (BoehringerMannheim). After incubation for various periods, digestion was terminated by the addition of $1 \mu \mathrm{l}$ of $10 \mathrm{mg} / \mathrm{ml}$ chymostatin (Boehringer-Mannheim), and samples were analyzed by native PAGE.

\section{Methylation interference analysis}

The 113-bp DdeI-NruI fragment (see Fig. 5C), 5' end-labeled at the DdeI site, was partially methylated with dimethylsulfate (Maxam and Gilbert 1980). The DNA was purified, incubated with $10 \mu$ l of early (1.5- to $4-\mathrm{hr}$ ) or $4 \mu \mathrm{l}$ of late (12- to $24-\mathrm{hr}$ ) embryo extract in a $20-\mu l$ volume under gel mobility-shift assay conditions and subjected to native PAGE. The gel regions containing specific protein-DNA complexes or unbound DNA were localized by autoradiography, excised, and eluted from the gel. The DNA was cleaved at sites of $G$ modification by piperidine treatment (Maxam and Gilbert 1980) and electrophoresed on a $8 \%$ sequencing gel.

\section{DNase I protection/gel mobility-shift analysis}

To obtain DNase I footprints on protein-DNA complexes using crude nuclear extracts, the specifically bound DNA was separated from unbound DNA by native gel electrophoresis. Extracts $[10 \mu \mathrm{l}$ of early (1.5- to $4-\mathrm{hr}$ ) and $10 \mu \mathrm{l}$ of late (16- to 19-hr) embryos] were incubated for $10 \mathrm{~min}$ at $25^{\circ} \mathrm{C}$ in a total volume of $50 \mu \mathrm{l}$ comprised of $5 \mu \mathrm{l}$ of $20 \mathrm{fmole} / \mu \mathrm{l}^{32} \mathrm{P}$-labeled DNA (the DdeI-NruI fragment of Fig. $2 \mathrm{~b}$ ), $5 \mu \mathrm{l} \mathrm{of} 10 \mathrm{mg} / \mathrm{ml}$ tRNA, $2.5 \mu \mathrm{l}$ of $4 \mathrm{mg} / \mathrm{ml}$ poly[d(I-C)] $\operatorname{poly}[\mathrm{d}(\mathrm{I}-\mathrm{C})], 2.5 \mu \mathrm{l}$ of 1 $\mathrm{mg} / \mathrm{ml}$ fragmented Escherichia coli DNA, and $25 \mu \mathrm{l}$ of binding buffer [150 mM NaCl, $30 \mathrm{~mm}$ Tris- $\mathrm{HCl}$ (pH 7.4), 1 mM DTT, 4 mM Na phosphate ( $\mathrm{pH} 7.0), 10 \%$ glycerol]. The samples were chilled on ice for $5 \mathrm{~min}$ before the addition of $5 \mu \mathrm{l}$ of $1 \mathrm{U} / \mu \mathrm{l}$ DNase I /Worthington DPRF; freshly diluted in $75 \mathrm{~mm} \mathrm{NaCl}$ and $11 \mathrm{mM} \mathrm{MgCl}_{2}$ ). The DNase I digestion proceeded on ice for $45 \mathrm{sec}$ before termination with $\mathrm{Na}_{2}$ EDTA to a final concentration of $20 \mathrm{~mm}$. After addition of $5 \mu \mathrm{l}$ of $5 \%$ BSA and $5 \mu \mathrm{l}$ of gel loading buffer $(2.5 \%$ Ficoll $400,0.5 \times$ TBE buffer, and tracking dyes|, the samples were electrophoresed at room temperature for $1 \mathrm{hr}$ at $70 \mathrm{~mA}$ on a submerged $1 \%$ agarose, $0.5 \times$ TBE gel. The gel was blotted for 3-4 hr at room temperature onto a DEAE membrane (Schleicher \& Schuell NA45), essentially according to the manufacturer's instructions. After location of the free and bound DNA by autoradiography, the DNA was recovered from the membrane slices by elution in $250 \mu \mathrm{l}$ of solution containing $1 \mathrm{M} \mathrm{NaCl}, 0.1 \mathrm{~mm}$ EDTA, $20 \mathrm{~mm}$ Tris- $\mathrm{HCl} / \mathrm{pH}$ 8.0 , and $2.5 \mu \mathrm{g}$ fragmented $E$. coli DNA. The DNA was purified by organic extraction and precipitated in ethanol, and equal amounts of radioactivity from the bound and unbound DNA were electrophoresed on an $8 \%$ sequencing gel.

\section{Nuclease protection analysis using purified late FTZ-F1}

For the upper strand footprint, 6 fmoles $(0.5 \mathrm{ng})$ of DNA was incubated for $15 \mathrm{~min}$ at $25^{\circ} \mathrm{C}$ in a $20-\mu \mathrm{l}$ volume containing 15 $\mathrm{mm}$ Tris- $\mathrm{HCl}(\mathrm{pH} 7.4), 100 \mathrm{~mm} \mathrm{NaCl}, 3 \mathrm{mM} \mathrm{MgCl}, 1 \mathrm{~mm}$ EDTA, $5 \%$ glycerol, $4 \mu \mathrm{g} / \mathrm{ml}$ fragmented E. coli DNA, $80 \mu \mathrm{g} / \mathrm{ml}$ tRNA, and $5 \mu \mathrm{l}$ of late embryo nuclear extract or 1 or $10 \mu \mathrm{l}$ of first-pass affinity-purified FTZ-F1 (the higher amount of FTZF1 was necessary to generate the DNase I footprint). Control digestions received no FTZ-F1 protein. Samples were then digested with 120 units of ExolII for $10 \mathrm{~min}$ at $30^{\circ} \mathrm{C}$ or with 4 
units of DNase I for $2 \mathrm{~min}$ at $25^{\circ} \mathrm{C}$. For the lower strand footprint, 8 fmole $(0.5 \mathrm{ng})$ of DNA was incubated under similar conditions in a $25 \mu \mathrm{l}$ volume containing $5 \mu \mathrm{l}$ of nuclear extract or $2.5 \mu \mathrm{l}$ or $12.5 \mu \mathrm{l}$ of first-pass affinity-purified FTZ-F1. Samples were then digested with 60 units of ExoIII or with 4 units of DNase I. All DNA samples were purified before electrophoresis on an $8 \%$ sequencing gel.

\section{Purification of FTZ-F1}

All procedures were performed at $4^{\circ} \mathrm{C}$, unless specified otherwise. Drosophila embryos (1.25 kg of 12 - to $24-\mathrm{hr}$ embryos) were homogenized in batches of $16 \mathrm{~g} \mathrm{embryos} / 40 \mathrm{ml} 1 \mathrm{M} \mathrm{su}$ crose/solution I (including $0.1 \mathrm{mM}$ EGTA) in a glass homogenizer with rotating Teflon pestle. Nuclear extracts were prepared essentially as above, except that the purified nuclei after sucrose gradient centrifugation were resuspended in solution I, pooled in one tube, and recentrifuged before extraction with solution II, dialysis in solution III $^{*}$ (solution III containing 0.25 mM EDTA), and storage at $-70^{\circ} \mathrm{C}$. Thawed nuclear extract (300 $\mathrm{ml} ; 3 \mathrm{mg} / \mathrm{ml}$ protein) was loaded on a $165-\mathrm{ml}$ heparin-Sepharose CL-6B column equilibrated in $0.1 \mathrm{M} \mathrm{NaCl}$ chromatography buffer (CB) (20 mM HEPES (pH 7.9), $0.1 \mathrm{~mm}$ EDTA, $0.5 \mathrm{~mm}$ DTT, $10 \%$ glycerol, $0.5 \mathrm{~mm}$ PMSF). The column was washed with several volumes of $0.1 \mathrm{M} \mathrm{NaCl} \mathrm{CB}$ and eluted with a 600 $\mathrm{ml}$ linear gradient of $0.3-1.3 \mathrm{M} \mathrm{NaCl} \mathrm{CB}$. Fractions of $11-\mathrm{ml}$ volume were collected and analyzed for FTZ-F1 activity by the gel mobility-shift assay. The activity eluted in fractions containing $0.6-0.9 \mathrm{M} \mathrm{NaCl} \mathrm{CB}$. Active fractions were pooled (165 ml), dialyzed in solution III $^{*}$ until the $\mathrm{NaCl}$ concentration was $0.15-0.2 \mathrm{M} \mathrm{NaCl}$ (one buffer change), and loaded at $1 \mathrm{ml} / \mathrm{min}$ on a 4-ml affinity column (first pass) constructed according to Wu et al. (1988). The affinity ligand consisted of two complementary synthetic oligonucleotides whose sequence is identical to the 33-bp DNA used to detect FTZ-F1 binding in the gel mobility-shift assay; in addition, a potential spacer was added by extending the lower strand by 10 bases from the $5^{\prime}$ end. The column was washed with $10 \mathrm{ml}$ of $0.1 \mathrm{M} \mathrm{NaCl} \mathrm{CB}$, and $10 \mathrm{ml}$ of $0.4 \mathrm{M} \mathrm{NaCl} \mathrm{CB}$, and eluted with $14.5 \mathrm{ml}$ of $1 \mathrm{M} \mathrm{NaCl} \mathrm{CB}$. The FTZ-F1 activity eluted in the first $6.5 \mathrm{ml}$ of the eluting buffer. After dialysis in solution III to reduce the $\mathrm{NaCl}$ concentration to $\sim 150 \mathrm{mM}$, poly[d(I-C)]-poly[d(I-C)] was added to a concentration of $10 \mu \mathrm{g} / \mathrm{ml}$, and the sample was loaded at $0.1 \mathrm{ml} / \mathrm{min}$ on a $0.4-\mathrm{ml}$ affinity column (second pass) equilibrated in $0.2 \mathrm{M} \mathrm{NaCl}$ $\mathrm{CB}$. The column was washed with $0.5 \mathrm{ml}$ of $0.2 \mathrm{M} \mathrm{NaCl} \mathrm{CB}$ and eluted at $0.02 \mathrm{ml} / \mathrm{min}$ with a $1.5-\mathrm{ml}$ gradient of $0.2-1.5 \mathrm{M} \mathrm{NaCl}$ $\mathrm{CB}$ (including $0.05 \% \mathrm{NP}-40$ ). Fractions of $0.1 \mathrm{ml}$ were collected; the FTZ-Fl activity eluted in $\sim 0.8 \mathrm{M} \mathrm{NaCl}$. Active fractions were pooled and the $\mathrm{NaCl}$ concentration was adjusted to about $0.2 \mathrm{M}$. The sample was loaded on a $0.05-\mathrm{ml}$ Mono S (Pharmacia) column at $0.05 \mathrm{ml} / \mathrm{min}$ and eluted at $0.02 \mathrm{ml} / \mathrm{min}$ with a $1 \mathrm{ml}$ gradient of $0.1-1.5 \mathrm{M} \mathrm{NaCl} \mathrm{CB}$. Fractions of $0.05 \mathrm{ml}$ were collected and assayed; the activity eluted in $\sim 0.5 \mathrm{M} \mathrm{NaCl}$.

\section{Preparation and analysis of antibodies}

Late FTZ-F1 $(0.5 \mu \mathrm{g})$ purified to the Mono S step (95\% homogeneity) was applied to each of three 4-mm square nitrocellulose membrane filters (Schleicher \& Schuell BA85). Each square was inserted subcutaneously in a dorsolateral location in one mouse. The procedure was repeated twice at 3-week intervals; serum was collected from the animal each subsequent week (Hazelton Laboratories, Virginia). The final immune serum reacted positively to $2.5 \mathrm{ng}$ of purified, native late FTZ-F1 protein dotted on nitrocellulose at $1: 5000$ dilution. Preimmune serum tested negative at dilutions of $1: 5000$ and lower.
Western blot analysis was performed by electrotransfer 1200 $\mathrm{mA}$ ) to nitrocellulose membrane in $25 \mathrm{mM}$ Tris base, $190 \mathrm{mM}$ glycine, and $20 \% \mathrm{MeOH}$ at $4^{\circ} \mathrm{C}$ overnight. The blot was stained with secondary antibody according to the manufacturer's directions.

\section{Vector construction}

A pC4neo-lacZ plasmid (Thummel et al, 1988) was partially digested with Sall, blunt-ended with Klenow, recircularized, and transformed into competent LM1035 cells. Vectors that retained only the polylinker Sall site were isolated, completely cut with Sall, blunt-ended, and ligated to XhoI linkers. This new vector, containing an $\mathrm{XhoI}$ site, was digested with $\mathrm{BamHI}$, blunt-ended, and ligated to KpnI linkers. This modified pC4neo-lacZ plasmid, containing both KpnI and XhoI sites, was named pKS1ßgal. A 4.4-kb EcoRI-Pst fragment from pKS1ßgal was then ligated to a pCaSpeR vector /V. Pirrotta, pers. comm.; see also Thummel et al. 1988) cut with EcoRI and PstI. This $4.4 \mathrm{~kb}$ EcoRI-PstI fragment contains the Adh gene ATG-initiating codon fused to the lacZ-coding region and the SV40 polyadenylation site. The resultant vector, $\mathrm{pCa}$ SpeRßgal(Xho) was used to build all subsequent promoter-fusion constructs.

\section{Zebra element-lacZ fusion gene constructs}

pftzNde, a plasmid harboring a ftz subclone with an engineered $\mathrm{NdeI}$ site at the $\mathrm{ftz}$-initiating ATG, was used to generate another plasmid containing only the first $1 \mathrm{~kb}$ upstream of the $f t z$ translational start site. pftzNde was cut to completion with Ndel, blunt-ended, ligated to Sall linkers, and recircularized. The 0.74-kb BalI-Sall fragment containing the ftz upstream sequences was subcloned into a SmaI-SalI-cut pEMBL19 vector and named p19BS. The $f t z$ upstream sequences were then excised as a $0.74 \mathrm{~kb} \mathrm{KpnI-SalI} \mathrm{fragment} \mathrm{and} \mathrm{inserted} \mathrm{upstream} \mathrm{of}$ the lacZ gene in a KpnI-XhoI cut pCaSpeRßgal vector to generate the nonmutated zebra element fusion construct, pBS $\beta$ gal.

\section{Mutant ftz promoter-lacZ fusion gene constructs}

To construct mutated zebra-lacZ fusion genes, a $0.67-\mathrm{kb}$ HindIII-NruI fragment, containing either of the two oligonucleotide-generated mutants for the FTZ-Fl-binding site I, was ligated along with a NruI-Sall 0.33-kb fragment from p19BS to a HindIII-SalI-digested pEMBL19 vector. The BalI-Sall fragments carrying the mutant binding sites were excised from the resulting mutated site-containing plasmids and were transferred to the $\mathrm{pCaSpeR} \beta \mathrm{gal}$ vector in a manner analogous to insertion of the nonmutated BalI-Sall fragment. A map of the pCaSpeRßgal vector with the zebra element insert is shown in Figure 8 . The resultant mutant promoter-fusion constructs were named pHU5-5 $\beta$ gal and pHU5-15 $\beta$ gal for the 4 - and the 2 -base change mutant, respectively. Both constructs were sequenced in the region of the FTZ-F1-binding site. All of the aforementioned constructs, including pBS $\beta$ gal, direct transcription from the white gene and lacZ fusion genes in opposite directions, from the middle of the vector toward the $\mathrm{P}$ element ends, so as to minimize position effects on the fusion gene.

\section{Germ line transformations}

$\mathrm{P}$ element-mediated germ line transformations were performed according to Rubin and Spradling (1982). The host Drosophila strain, $D f(1) w 67 c 2$ (obtained from V. Pirrotta) was injected with 200-400 $\mu \mathrm{g} / \mathrm{ml} \mathrm{pBS \beta gal,} \mathrm{pHU5-5 \beta gal,} \mathrm{or} \mathrm{pHU5-15 \beta gal} \mathrm{DNA}$ 


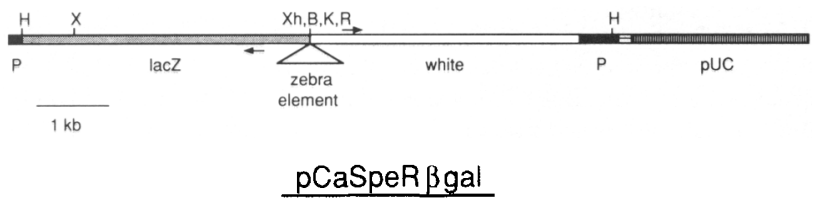

Figure 8. A map of the zebra element-containing P-element transformation vector (drawn to scale). Both the unmutated and mutated versions of the zebra element were inserted upstream of the $\operatorname{lac} Z$ gene in the proper $5^{\prime} \rightarrow 3^{\prime}$ orientation. The solid portion represents P-element sequences; the striped portions, pUC sequences; the stippled portions, lac $Z$ sequences; and the open portions, white sequences. Restriction sites are noted: HindIII (H); XbaI (X); XhoI (Xh);BamHI (B); KpnI $(\mathrm{K}) ; \operatorname{EcoRI}(\mathrm{R})$. The directions of transcription of the white and lac $Z$ genes are indicated by arrows.

plus $75-100 \mu \mathrm{g} / \mathrm{ml}$ p $\delta 2-3 w c$ helper DNA. Individual $\mathrm{G}_{0}$ flies were mated to $D f(1) w 67 c 2$ flies, and the resultant $G_{1}$ progeny scored for partial rescue of the $w^{-}$phenotype. Individual $G_{1}$ progeny showing $\mathrm{w}^{+}$activity were mated to $D f(1) \mathrm{w} 67 \mathrm{c} 2 \mathrm{flies}$, and the resultant $G_{2}$ heterozygotes were backcrossed. Virgins and males with a darker eye color were then backcrossed to establish a homozygous line. Males from transformant lines were mated to virgins from balancer stocks for the third chromosome $(w ; T M 3 U b \mathrm{x} / T M 6 b)$ or for the second chromosome (w; Sco/CyO). The results of these crosses yielded linkage group assignments for most of the transformant lines, and the crosses served to separate multiple insertion events. Only those lines established from different $\mathrm{G}_{0}$ parents and backcrossed so that the insert was homozygous were used in the X-gal and immunostaining experiments.

\section{$X-g a l$ and immunohistochemical staining of embryos}

$\mathrm{X}$-gal staining of transformant lines was performed according to Simon et al. (1985) except that embryos were fixed by shaking in a $1: 4$ ratio of $4 \%$ paraformaldehyde /freshly prepared in $1 \times \mathrm{PBS}$ ) to heptane for $30 \mathrm{~min}$ at room temperature. Alternatively, formaldehyde stored under anoxic conditions in the absence of methanol was also used as a fixative.

The expression of $\beta$-galactosidase was also assayed by indirect immunohistochemical staining according to Carroll and Scott (1986), with the following revisions: Embryos were dechorionated in $60 \%$ bleach for no longer than $2 \mathrm{~min}$ and rinsed with water for several min. They were then placed into a $1: 2$ to $1: 4$ mixture of $4 \%$ formaldehyde (made up in $1 \times \mathrm{PBS}$ ) and heptane and agitated for $30 \mathrm{~min}$. The aqueous phase was then pipetted off first, followed by the heptane phase. An emulsion of a $1: 1 \mathrm{mix}$ of heptane and methanol was pipetted vigorously over the embryos several times to devitellinize them. The embryos that had sunk to the bottom of the methanol phase were rinsed once with fresh methanol and then with $1 \times \mathrm{PBS}, 0.1 \%$ Triton X-100, 0.2\% BSA (PBT-BSA). The PBT-BSA was replaced with $200 \mu l$ of a $1: 1000$ dilution of a primary mouse monoclonal anti- $\beta$-gal antibody diluted into PBS-BSA and incubated with shaking at $4^{\circ} \mathrm{C}$ overnight. The embryos were washed at room temperature for $2 \min (3 \times)$ with PBT-BSA and then for $30 \mathrm{~min}(9 \times)$ with PBT-BSA. The last PBT-BSA wash was replaced by a wash with $200 \mu$ l of a $1: 200$ dilution of a secondary goat anti-mouse antibody conjugated to horseradish peroxidase for $2 \mathrm{hr}$, shaking at room temperature. Excess secondary antibody was rinsed out by washing embryos at room temperature for $2 \mathrm{~min}(3 \times)$ with PBT-BSA and then for $30 \mathrm{~min}$ $(4 \times)$ with PBT - BSA before staining. Staining was carried out in
$200 \mu \mathrm{l}$ of $0.5 \mathrm{mg} / \mathrm{ml}$ diaminobenzidine, $0.4 \mathrm{mg} / \mathrm{ml} \mathrm{NiCl} / 2 \mathrm{H}_{2} 0$ in PBT-BSA plus $0.0015 \% \mathrm{H}_{2} \mathrm{O}_{2}$ at room temperature for several minutes.

We observed some variation in the staining pattern in embryos carrying wild-type zebra-lac $Z$ constructs. In all six wildtype transformant lines, a small fraction of embryos show depressed staining of stripes 2,3 , and 6, similar to, but not as severe as, the changes observed for embryos carrying the mutant constructs. This fraction represents $1-10 \%$ of the embryo population and may result from the relative deficiency in the number of FTZ-Fl-binding sites within the zebra-lacZ construct.

\section{Acknowledgments}

We thank Barbara Davis for her superb management of the National Institutes of Health (NIH) Drosophila colony, following procedures established by Anthony Mahowald and Allan Spradling. We also thank Giovanni Lavorgna for sharing nuclear extracts, Peter Becker and John Tamkun for remapping the $f t z$ transcription start site, Rick Schaaf and Paula Zegob for help in maintaining fly strains, Ann Boulet for helping construct P-element vectors, Mike Brownstein for preparing synthetic oligonucleotides, and Judy Kassis, Jim Kennison, Yash Hiromi, and members of our laboratories for helpful suggestions, criticisms, and comments on the manuscript. This work was supported by the National Cancer Institute Intramural Research Program, by a grant to M.P.S. from the American Cancer Society and, in part, by the Ministry of Education, Science, and Culture of Japan (Priority area \#62124047).

\section{References}

Akam, M. 1987. The molecular basis for metameric pattern in the Drosophila embryo. Development 101: 1-22.

Biggin, M.D. and R. Tjian. 1988. Transcription factors that activate the Ultrabithorax promoter in developmentally staged extracts. Cell 53: 699-711.

Carroll, S.B. and M.P. Scott. 1985. Localization of fushi tarazu protein during Drosophila embryogenesis. Cell 43: 47-57.

. 1986. Zygotically active genes that affect the spatial expression of the fushi tarazu segmentation gene during early Drosophila embryogenesis. Cell 45: 113-126.

Dearolf, C.R., J. Topol, and C.S. Parker. 1989. Transcriptional control of Drosophila fushi tarazu zebra stripe expression. Genes Dev. 3: 384-398.

Doe, C.Q., Y. Hiromi, W.J. Gehring, and C.S. Goodman, C.S. 1988. Expression and function of the segmentation gene fushi tarazu during Drosophila neurogenesis. Science 239: $170-175$

Edgar, B.A., M.P. Weir, G. Schubiger, and T. Kornberg, T. 1986. Repression and turnover pattern fushi tarazu RNA in the early Drosophila embryo. Cell 47: 747-754.

Fitzpatrick, V.D. and C.J. Ingles. 1989. The Drosophila fushi tarazu polypeptide is a DNA-binding transcriptional activator in yeast cells. Nature 337: 666-668.

Frasch, M. and M. Levine. 1987. Complementary patterns of even-skipped and fushi tarazu expression involve their differential regulation by a common set of segmentation genes in Drosophila. Genes Dev. 1: 981-995.

Gehring, W.J. 1987. Homeoboxes in the study of development. Science 236: 1245-1252.

Gehring, W.J. and Y. Hiromi. 1986. Homeotic genes and the homeobox. Annu. Rev. Genet. 20: 147-173.

Hafen, E., A. Kuroiwa, and W.J. Gehring, W.J. 1984. Spatial dis- 
tribution of transcripts from the segmentation gene fushi tarazu during embryonic development. Cell 37: 833-841.

Han, K., M.S. Levine, and J.L. Manley, J.L. 1989. Synergistic activation and repression of transcription of Drosophila homeobox proteins. Cell 56: 573-583.

Harrison, S.D. and A.A. Travers. 1988. Identification of the binding sites for potential regulatory proteins in the upstream enhancer element of the Drosophila fushi tarazu gene. Nucleic Acids Res. 16: 11403-11416.

Hiromi, Y. and W.J. Gehring, W.J. 1987. Regulation and function of the Drosophila segmentation gene fushi tarazu. Cell 50: $963-974$.

Hiromi, Y., A. Kuroiwa, and W.J. Gehring, W.J. 1985. Control elements of the Drosophila segmentation gene fushi tarazu. Cell 43: 603-613.

Howard, K.R. and P.W. Ingham, P.W. 1986. Regulatory interactions between the segmentation genes fushi tarazu, hairy, and engrailed in Drosophila blastoderm. Cell 44: 949-957.

Ingham, P.W. 1988. The molecular genetics of embryonic pattern formation in Drosophila. Nature 335: 25-34.

Jaynes, J.B. and P.H. O'Farrell. 1988. Activation and repression of transcription by homeodomain-containing proteins that bind a common site. Nature 336: 744-749.

Jürgens, G., E. Wieschaus, C. Nüsslein-Volhard, and H. Kluding. 1984. Mutations affecting the pattern of the larval cuticle in Drosophila melanogaster. II. Zygotic loci on the third chromosome. Wilhelm Roux's Arch. Dev. Biol. 193: 283-295.

Krause, H.M., R. Klemenz, and W.J. Gehring. 1988. Expression, modification and localization of the fushi tarazu protein in Drosophila embryos. Genes Dev. 2: 1021-1036.

Kuroiwa, A., E. Hafen, and W.J. Gehring. 1984. Cloning and transcriptional analysis of the segmentation gene fushi tarazu of Drosophila. Cell 37: 825-831.

Laughon, A. and M.P. Scott. 1984. Sequence of a Drosophila segmentation gene: Protein structure homology with DNAbinding proteins. Nature 310: $25-31$.

Lawrence, P.A., P. Johnston, P. Macdonald, and G. Struhl. 1987. Borders of parasegments in Drosophila embryos are delimited by the fushi tarazu and even-skipped genes. Nature 328: 440-442.

Mahoney, P.A. and J.A. Lengyel, J.A. 1987. The zygotic segmentation mutant tailless alters the blastoderm fate map of the Drosophila embryo. Dev. Biol. 122: 464-470.

Maniatis, T., E.F. Fritsch, and J. Sambrook. 1982. Molecular cloning: A laboratory manual. Cold Spring Harbor Laboratory Press, Cold Spring Harbor, New York.

Marzouki, N., S. Camier, A. Ruet, A. Moenne, and A. Sentenac, 1986. Selective proteolysis defines two DNA-binding domains in yeast transcription factor tau. Nature 323: 176178.

Maxam, A.M. and W. Gilbert. 1980. Sequencing end-labeled DNA with base-specific chemical cleavages. Meth. Enzym. 65: 409-560.

Nüsslein-Volhard, C. and E. Wieschaus. 1980. Mutations affecting segment number and polarity in Drosophila. Nature 287: 795-801.

Nüsslein-Volhard, C., E. Wieschaus, and H. Kluding. 1984. Mutations affecting the pattern of the larval cuticle in Drosophila melanogaster. I. Zygotic loci on the second chromosome. Wilhelm Roux's Arch. Dev. Biol. 193: 267-282.

Nüsslein-Volhard, C., H.G. Frohnhofer, and R. Lehmann. 1987.

Determination of anteroposterior polarity in Drosophila. Science 238: 1675-1681.

Perkins, K.K., G.M. Dailey, and R. Tjian. 1988. In vitro analysis of the Antennapedia P2 promoter: Identification of a new Drosophila transcription factor. Genes Dev. 2: 1615-1626.
Perrimon, N. and A.P. Mahowald. 1988. Maternal contributions to early development in Drosophila. In Developmental genetics of higher organisms (ed. G. Malacinski), pp. 305-328, Macmillan, New York.

Perrimon, N., L. Engstrom, and A.P. Mahowald. 1984. The effects of zygotic lethal mutations on female germ-line functions in Drosophila. Dev. Biol. 105: 404-414.

Perrimon, N., L. Engstrom, and A.P. Mahowald. 1989. Zygotic lethals with specific maternal phenotypes in Drosophila melanogaster. I. Loci on the $\mathrm{X}$ chromosome. Genetics 121: 333-352.

Rubin, G.M. and A.C. Spradling. 1982. Genetic transformation of Drosophila with transposable element vectors. Science 218: $348-353$.

Scott, M.P. and S.B. Carroll. 1987. The segmentation and homeotic gene network in early Drosophila development. Cell 51: $689-698$.

Scott, M.P., J.W. Tamkun, and G.W. Hartzell. 1989. The structure and function of the homeodomain. BBA Rev. Cancer 989: $25-48$.

Simon, J.A., C.A. Sutton, R.B. Lobell, R.L. Glaser, and J.T. Lis. 1985. Determinants of heat shock induced chromosome puffing. Cell 40: 805-817.

Soeller, W.C., S.J. Poole, and T. Kornberg. 1988. In vitro transcription of the Drosophila engrailed gene. Genes Dev. 2: $68-81$.

Thummel, C., A. Boulet, and H. Lipshitz. 1988. Vectors for Drosophila $\mathrm{P}$ element-mediated transformation and tissue culture transfection. Gene 74: 445-456.

Wakimoto, B.C. and T.C. Kaufman. 1981. Analysis of larval segmentation in lethal genotypes associated with the Antennapedia gene complex in Drosophila melanogaster. Dev. Biol. 81: $51-54$

Weiner, A.J., M.P. Scott, and T.C. Kaufman. 1984. A molecular analysis of fushi tarazu, a gene in Drosophila melanogaster that encodes a product affecting embryonic segment number and cell fate. Cell 37: 843-851.

Weir, M.P. and T. Kornberg. 1985. Patterns of engrailed and fushi tarazu transcripts reveal novel intermediate stages in Drosophila segmentation. Nature 318: 433-439.

Wieschaus, E., C. Nüsslein-Volhard, and G. Jürgens. 1984. Mutations affecting the pattern of the larval cuticle in Drosophila melanogaster. III. Zygotic loci on the X-chromosome and the fourth chromosome. Wilhelm Roux's Arch. Dev. Biol. 193: 296-307.

Winslow, G.M., S. Hayashi, M. Krasnow, D.S. Hogness, and M.P. Scott. 1989. Transcriptional activation by the Antennapedia and fushi tarazu proteins in cultured Drosophila cells. Cell 57: 1017-1030.

Wu, C., S. Wilson, B. Walker, I, Dawid, T. Paisley, V. Zimarino, and H. Ueda. 1987. Purification and properties of Drosophila heat shock activator protein. Science 238: 1247-1253.

Wu, C., C. Tsai, and S. Wilson. 1988. Affinity chromatography of sequence-specific DNA-binding proteins. Genet. Eng. 10: $67-74$. 


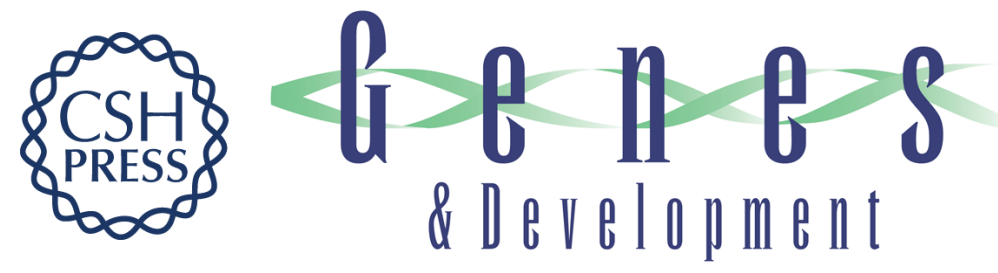

\section{A sequence-specific DNA-binding protein that activates fushi tarazu segmentation gene expression.}

H Ueda, S Sonoda, J L Brown, et al.

Genes Dev. 1990, 4:

Access the most recent version at doi:10.1101/gad.4.4.624

References This article cites 46 articles, 12 of which can be accessed free at:

http://genesdev.cshlp.org/content/4/4/624.full.html\#ref-list-1

License

Email Alerting

Service

Receive free email alerts when new articles cite this article - sign up in the box at the top right corner of the article or click here.

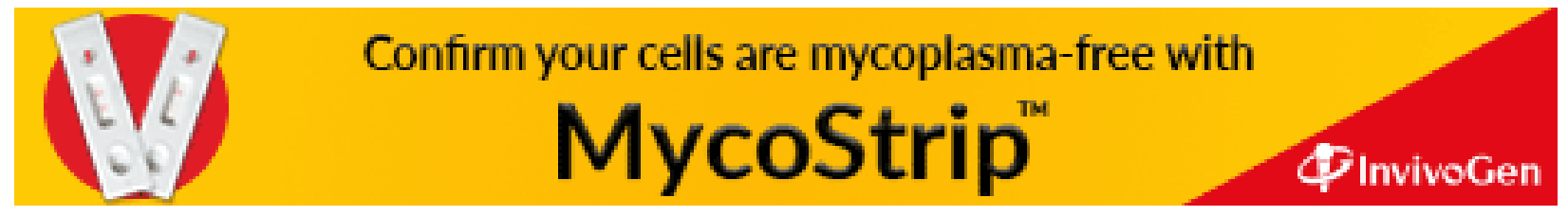

